\title{
Siste vers for Michael Jackson
}

Etter Michael Jacksons (1958-2009) tragiske død 25.6. 2009 har vi nylig vært vitne til en kraftig eksponert rettssak som foreløpig endte med at legen Conrad Murray ble funnet skyldig i uaktsomt drap på popstjernen. Saken reiser spørsmål knyttet til anestesimidlet propofol, hvem som kan bruke det og til utfordringer i lege-pasientforholdet når pasienten er megastjerne.

Retten mente at Jackson trolig døde av respirasjonsstans forårsaket av propofol i kombinasjon med høye doser av konvensjonelle benzodiazepiner. Murray, som er kardiolog, hadde behandlet Jackson $i$ hans hjem for søvnvansker og bl.a. regelmessig administrert propofol intravenøst for å få ham til å sove. Rettssaken dreide seg om Murray var kompetent til å bruke propofol, om han hadde etablert nødvendige sikkerhetsrutiner knyttet til bruken og om han hadde gitt Jackson store doser uten å overvåke ham ordentlig. Legens forsvarere hevdet at Jackson måtte ha satt en dose på seg selv etter at han ble alene på soveværelset, mens aktoratet hevdet at Murray måtte ha gitt alt sammen. De sakkyndige anestesiprofessorene Paul White og Steve Shafer var sterkt uenige om dette siste, og man kan trolig forvente nye runder i retten. Imidlertid er det enighet om at Murray ikke var kompetent til å bruke propofol under slike forhold samt at hans tilnærming til bruk, nødvendig overvåking og beredskap var klart i strid med faglige retningslinjer (Paul White, personlig meddelelse).

Propofol er trolig det mest brukte midlet for oppstart av generell anestesi i den vestlige verden (1). Det må gis intravenøst, og pasienten sovner i løpet av få minutter. Etter en enkeltdose opplever man en behagelig, litt euforisk oppvåkning 5-10 minutter senere (2). Propofol brukes dessuten mye som kontinuerlig infusjon for å sikre langvarig og raskt reversibel søvn under generell anestesi og i intensivavdelinger. Det er gjort lovende forsøk på kontrollert lavdosert propofol for å behandle konvensjonelle søvnvansker, men slik bruk er foreløpig eksperimentell (3). Som ved nesten alle generelle anestesimidler vil propofol i økende dose innebære at pasienten ikke klarer å holde frie luftveier eller puste selv. Den som gir midlet, må alltid overvåke pustefunksjonen kontinuerlig og ved behov kunne assistere eller overta pustefunksjonen for pasienten. Samme krav gjelder også når propofol brukes i lave doser for å få en pasient til å slappe av eller småsove (sedasjon) med intakt pustefunksjon, f.eks. ved bruk av regional anestesi.

I Norge er bruken av propofol regulert i Felleskatalogen (4) og i Standard for anestesi $(5,6)$, som sier at midlet kun skal brukes av anestesileger eller anestesisykepleiere og alltid med spesifiserte krav til overvåking og beredskap. I Europa og USA diskuteres det om propofol også kan tas i bruk i lave doser av andre leger og helsepersonell for våken sedasjon, f.eks. ved gastroskopi og intervensjonsradiologi. I et ferskt europeisk konsensusdokument konkluderte man med at en ansvarlig lege, sammen med en spesialtrent medhjelper til å passe på pustefunksjonen kontinuerlig, burde kunne gi propofol på denne måten (7). Nødvendige krav til medhjelpers kompetanse er såpass omfattende at det nærmer seg det som kreves for å bli anestesisykepleier i Norge. I en rekke europeiske land har de anestesiologiske spesialistforeningene uttalt at man må ha eksplisitt anestesiologisk kompetanse for å kunne gi propofol (8). Også i USA skal midlet i utgangspunktet kun administreres av anestesiologer eller anestesisykepleiere, men Murray var omfattet av en ordning hvor han var sertifisert til å bruke propofol i arbeidet på en klinikk han var tilknyttet (Paul White, personlig meddelelse).

Propofol gitt av kvalifisert anestesipersonell i Norge er helt trygt. Man anslår at én av 200000 pasienter opplever fatale feil knyttet til generell anestesi $(8,9)$, og i disse få tilfellene har ikke problemet vært knyttet til bruk av propofol. For å berolige engstelige pasienter kan propofol og generell anestesi gjerne sammenliknes med det å fly. De fleste opplever en flyreise som trygg så lenge man har kvalifisert personell om bord.

Murrays rolle som behandlende lege for Michael Jackson er interessant. Han var en etablert kardiolog med praksis, men tok på seg oppgaven med å hjelpe megastjernen på heltid i en periode. Han ble i noen grad en av Jacksons få fortrolige. Han opplevde en pasient som følte seg ensom, men som var krevende og ikke alltid fulgte hans anvisninger. Jackson hadde brukt benzodiazepiner, petidin og propofol under varierende oppsyn av mange forskjellige leger gjennom mange år. Han bedrev selvmedisinering, også intravenøst, i tillegg til det som ble ordinert (Paul White, personlig meddelelse).

Omstendighetene rundt Jacksons død gir oss en viktig påminnelse om at vi aldri må begi oss inn på faglig uforsvarlige tilpasninger når vi tar på oss rollen som behandlende lege. Vi kan heller ikke melde oss ut av farmakologiens naturlover. Trygge medikamenter med kraftige fysiologiske effekter vil kunne gi farlige bivirkninger ved ukvalifisert bruk.

\section{Johan Ræder}

johan.rader@medisin.uio.no

Avdeling for anestesiologi

Oslo universitetssykehus, Ullevål

Johan Ræder (f. 1954) er seksjonsoverlege ved Avdeling for anestesiologi ved Oslo universitetssykehus, Ullevål, og professor II ved Det medisinske fakultet, Universitetet i Oslo.

Ingen oppgitte interessekonflikter.

\section{Litteratur}

1. Hartle A, Malhotra S. The safety of propofol. BMJ 2009; 339: b4024.

2. Raeder J. Pharmacology. I: Raeder J, red. Clinical ambulatory anesthesia. Cambridge: Cambridge University Press, 2011: 58-9

3. Xu Z, Jiang X, Li W et al. Propofol-induced sleep: efficacy and safety in patients with refractory chronic primary insomnia. Cell Biochem Biophys 2011; 60 : $161-6$.

4. Diprivan. www.felleskatalogen.no/ (23.11.2011).

5. Standard for anestesi. www.nafweb.no/ index. php?option=com_content\&view=article \&id $=100079$ standard-for-anestesi\&catid=38: standarder\&Itemid=27 (23.11.2011).

6. Gisvold SE, Raeder J, Jyssum T et al. Guidelines for the practice of anesthesia in Norway. Acta Anaesthesiol Scand 2002; 46: 942-6.

7. Dumonceau JM, Riphaus A, Aparicio JR et al. European Society of Gastrointestinal Endoscopy, European Society of Gastroenterology and Endoscopy Nurses and Associates, and the European Society of Anaesthesiology Guideline: Non-anaesthesiologist administration of propofol for Gl endoscopy. Eur J Anaesthesiol 2010; 27: 1016-30.

8. Perel A. Non-anaesthesiologists should not be allowed to administer propofol for procedural sedation: a consensus statement of 21 European national societies of anaesthesia. Eur J Anaesthesiol 2011; 28: 580-4.

9. Fasting S. Risiko ved anestesi. Tidsskr Nor Legeforen 2010; 130: 498-502. 